\title{
Theories of Money in Argentine Crime Fiction
}

\section{Abstract}

Much recent writing on crime fiction and on Latin American crime fiction in particular has focused on the genre's potential for social and political critique. This article aims to examine the specific case of money in Argentine crime fiction. It argues that in a number of Argentine novels dealing with crime, money is more than just a leitmotif or theme: it is a character in itself. Money has a role to play, almost a certain protagonism which, in some cases, is even titular. Furthermore, one can identify what might be called 'theories of money' in crime novels. Novelists are interested not just in the way that money motivates or changes people's behaviour but also in how money itself behaves. Through examining money's role in crime, novelists are asking what money actually is, a question that to this day baffles many economists. We aim therefore to trace a lineage in Argentine fiction of novelists who give money a central role in fictions about crime, starting with Roberto Arlt, and then moving on to more recent writers, Ricardo Piglia, Ernesto Mallo, Carlos Gamerro, and Alan Pauls.

Keywords

Argentina.

Literature.

Contemporary fiction.

Crime novels.

Theories of money. 
Theories of Money in Argentine Crime Fiction

Much recent writing on crime fiction and on Latin American crime fiction in particular has focused on

the genre's potential for social and political critique. ${ }^{1}$ This article aims to examine the specific case of

money in Argentine crime fiction. The starting premise is quite simple: Argentine crime fictions present

the reader with theories about the nature of money. ${ }^{2}$ In 'classic' detective fiction, money plays a

variable role. Money - as opposed to sheer power or influence - is rarely the motivation in Edgar Allan

Poe's seminal detections. Detectives themselves are seldom motivated by money in classic crime

fiction. ${ }^{3}$ But one of the first 'modern' detective stories, E.C. Bentley's Trent's Last Case (1913), ${ }^{4}$ features

\footnotetext{
${ }^{1}$ An important early study of the detective genre can be found in Régis Messac, Le 'detective novel' et l'influence de la pensée scientifique (Paris: H. Champion, 1929). More recent studies worthy of note include Stephen Knight, Form and Ideology in Crime Fiction (London: Macmillan, 1980) and Ernst Mandel, Delightful Murder. A Social History of the Crime Story (London: Pluto, 1984) as well as the section 'Clues' in Franco Moretti, Signs Taken for Wonders. Essays in the Sociology of Literary Form, trans. Susan Fischer (London: Verso, 1988) and the essay by Gilles Deleuze, 'The Philosophy of Crime Novels,' in Desert Islands and Other Texts 1953-1974, trans. Michael Taormina (Los Angeles; New York: Semiotext(e), 2004), 81-85. There has been a wave of recent primers and handbooks on the genre, for example Peter B Messent, The Crime Fiction Handbook (Chichester: Wiley-Blackwell, 2013), or Luc Boltanski, Mysteries and Conspiracies, trans. Catherine Porter (Cambridge: Polity, 2014). On Latin American crime, see Donald A. Yates, El cuento policial latinoamericano (México DF: Andrea, 1964), an anthology with an excellent introduction; see also works by Mempo Giardinelli, El género negro, 2 vols. (México DF: UAM, 1984), Leonardo Padura, Modernidad, posmodernidad y novela policial (La Habana: Unión, 2000) and Amelia Simpson, Detective Fiction from Latin America (Rutherford: Farleigh Dickinson, 1990). On Argentina, the work of Jorge Lafforgue and Jorge B. Rivera, Asesinos de papel. Ensayos sobre narrativa policial (Buenos Aires: Colihue, 1996) remains, in my opinion, unsurpassed. Also worthy of attention are Carlos Gamerro, 'El nacimiento de la literatura Argentina' y otros ensayos (Buenos Aires: Norma, 2006) and Josefina Ludmer, El cuerpo del delito. Un manual (Buenos Aires: Eterna Cadencia, 2011[1 $1^{\text {st }}$ ed. 1999]), to name just two valuable studies.

2 This article adopts a basic and inclusive definition of the form. Put simply, crime fiction is fiction that is predominantly about crime; the work does not have to self-identify as genre fiction. More specifically, it is about the committing of a crime, and about attempts to stop, identify, or apprehend the criminal. The crime in question needs to be a serious crime, or at least to be perceived as a serious crime (murder, robbery, rape, kidnap, etc).

${ }^{3}$ See the letters by Charles Rzepka (20 March) and David Campbell (3 April) in response to Alice Spawls' article in London Review of Books (Alice Spawls, 'How Did She Get Those Feet?' LRB 36.4 (20 February 2014), 27-28.

http://www.Irb.co.uk/v36/n04/alice-spawls/how-did-she-get-those-feet [last accessed 4 July 2014], discussing whether Sherlock Holmes is motivated by money or not.

${ }^{4}$ E. C. Bentley, Trent's Last Case (Oxford: OUP, 1995).
} 
the murder of a wealthy financier and money is at the heart of its plot. ${ }^{5}$ In Agatha Christie's novels, for example, an inheritance can easily motivate murder. Robberies of money and property - particularly jewels - are popular themes for crime fiction in the twentieth century. Latin American classic crime fiction - of the type promoted by Jorge Luis Borges and anthologized by Yates ${ }^{6}$ - includes thefts and money-motivated crimes in its plots. ${ }^{7}$ The Chilean Alberto Edwards aka Miguel Fuenzalida, famous for his reworking of the Holmes model in the shape of Román Calvo, included greed and meanness as motivations for crime. Indeed the Mexican crime writer Antonio Helú even features a robber, Máximo Roldán, as his detective. His surname is, of course, an anagram of 'ladrón'. As Mempo Giardinelli commented, lack of money or battles for money are clear motivations for US hardboiled crime fictions. ${ }^{8}$ The Private Investigator does work for money; Raymond Chandler's detective Philip Marlowe, in novels such as The Big Sleep (1939), sets out his financial terms and conditions to his wealthy client from the start. In the Latin American 'negra' or 'dura' (hardboiled), Giardinelli argues that the social context of a lack of money and the factors that lead to inequality, are examined by writers. Whereas the US hardboiled is based on money, in Latin America it focuses on the social differences that lead to having, or not having, money. ${ }^{9}$ Characters in Latin American 'negras' are seldom purely motivated by money.

This article argues that there is something more striking in a number of Argentine novels, namely that money is more than just a theme: it is a character. Money has a role to play, almost a certain protagonism, which in some cases, as shall be seen below, is even titular. Furthermore, one can identify what might be called 'theories of money' in crime novels. Novelists are interested not just in the

\footnotetext{
${ }^{5}$ I am grateful to Simão Valente for this observation, and also his generous and insightful contribution as a member of the audience during my lecture course, 'Crime in Latin American Fiction', Trinity Term 2014, University of Oxford.

${ }^{6}$ Donald A. Yates, El cuento policial latinoamericano (México DF: Andrea, 1964).

${ }^{7}$ In María Angélica Bosco's clever variations on the Marples-style detective, for example La muerte soborna a Pandora (Buenos Aires: Conjunta, 1977 [1st ed. 1956]) and Historia privada (Buenos Aires: Emecé, 1972) money tends to offer motivation for certain characters, but not necessarily for the criminal act itself.

${ }^{8}$ Mempo Giardinelli, El género negro, 2 vols (México DF: UAM, 1984).

${ }^{9}$ Giardinelli, El género negro, II, p. 33.
} 
way that money motivates or changes people's behaviour but also in how money itself behaves.

Through examining money's role in crime, novelists are asking what money actually is, a question that to this day baffles economists. ${ }^{10}$

We aim therefore to trace a lineage, in this case in Argentine fiction, of novelists who give money a central role in fictions about crime, starting with Roberto Arlt, and then moving on to more recent novelists, Ricardo Piglia, Ernesto Mallo, Carlos Gamerro, and Alan Pauls.

Theories of Money

The simplest, and most widely accepted theory of money, for conservative and Marxist theorists alike, begins with barter. Society starts its process of exchange by barter: A offers B a good, and B offers A one back. This is based on need. A has bananas, but man cannot live on bananas alone, so swaps them for some of B's meat. This is complicated and time consuming, not least because it means one constantly has to carry things to and from one or another market. So, over time, a mutual equivalent is introduced. At first this is something that is viewed as having some value in itself, such as a rare or precious metal. Gold and silver are good for this purpose, as they are relatively sparse but can be turned into coins with only limited technique. Coins work as a universal equivalent, and this facilitates trade. Over time, the preciousness of the metal ceases to be so important, and instead forms of token are introduced.

Banknotes are one more advanced form. Eventually, things come to be recorded, and so actually the object itself ceases to be important. This is the birth of the credit-debit system.

This is, by and large, the model that Marx takes up in Capital, ${ }^{11}$ whereby the money form is a way of making different goods in some way equivalent. Marx adopts what is known as the labour theory

\footnotetext{
${ }^{10}$ I am grateful to Philip Derbyshire for this observation. See Geoffrey Ingham, The Nature of Money (Cambridge: Polity, 2004, 3) for a clear and amusing example of this ignorance.

${ }^{11}$ Karl Marx, Capital. A New Abridgement (Oxford: Oxford U. P., 1999).
} 
of value. What money is really measuring in exchange value is the amount of socially necessary labour required for a given amount of a particular good. Commodities circulate in simple fashion thus: A makes a commodity; A sells it for money; A buys another commodity (one he needs - e.g. a wheat farmer sells wheat to buy food, clothes, tools, etc.). But there is another mode of circulation, which is that of capital: A uses money to buy a commodity to sell for money. Marx called these two forms of circulation C-M-C and $\mathrm{M}-\mathrm{C}-\mathrm{M}$. The aim of the capitalist was to turn money into more money, or $\mathrm{M}-\mathrm{C}-\mathrm{M}^{\prime}{ }^{12}$ The additional money, or surplus value, comes from the unpaid labour the capitalist extracts from the worker at some stage during the production process.

For Marx, the mystery of the commodity was that it seemed to express in objective characteristics, as a property of the thing or good, what are in fact social characteristics related to human labour. A bushel of wheat costs six shillings, say, and that seems to be an objective quality. In fact it reflects a whole network of human relationships. For Marx, this was the origin of what is called the 'fetish' character of the commodity.

A version of this theory is found in George Simmel's The Philosophy of Money. ${ }^{13}$ George Simmel starts from the principle of money as the universal equivalent. Money is the way by which we give meaning to the relationship between things. It represents our ability to construct 'symbolic concepts', ${ }^{14}$ to 'make comprehensible the most abstract concept'. ${ }^{15} \mathrm{He}$ goes on to argue that money is the symbol of modernity, of the dynamic character of the world, or perpetual movement. But it is not simply an economic value, but also abstract value in general. It is the connection of various elements. Simmel took

${ }^{12}$ Wolfgang Streeck argues that the financial crisis of 2008 had its roots in an attempt to move from the M-C-M' formula to, by the medium of complex financial instruments, a formula that would simply give $M-M^{\prime}$, a form of what might be called financial alchemy ('How Will Capitalism End', New Left Review 87 (May-June 2014), 35-66 esp. p. 52ff).

${ }^{13}$ George Simmel, The Philosophy of Money, trans. Tom Bottomore and David Frisby. 2nd ed. (London: Routledge, 1990).

${ }^{14}$ Simmel, The Philosophy of Money, 129.

${ }^{15}$ Simmel, The Philosophy of Money, 129. 
issue with Marx's labour theory of value, by which money has meaning because it can express a

relationship to socially necessary labour. For Simmel, though, unlike labour, which could not be properly compared in such a relationship, 'the essence of all money, however, is its unconditional

interchangeability'. ${ }^{16}$ Simmel argues, against Marx, that 'physical labour is not the sole creator of value'.

Both thinkers agree, however, on the basic barter-money-credit sequence.

David Graeber is one of a number of recent theorists who reject the barter-money-credit model. ${ }^{17}$ Based on anthropological evidence, he argues that there is no proof of 'primitive' barter. There exist no societies in which people swap goods in the way that economists claim they do. Instead, the very earliest forms of exchange already include credit. While gold and silver were tremendously important in the early modern age, we find records of credit and debt in some of the earliest societies with writing, such as the Minoan culture of today's Crete. Early writing includes records of debt because these are fundamental to forms of human exchange. Money follows debt, and barter may even follow money, argues Graeber. He sees a constant oscillation between credit money and bullion money, with periodic crises leading to credit crunches or currency crashes. Currency (i.e. coins) has its origins in warfare and in particular in looting, when the ability to turn objects of useful or ceremonial value into a transportable equivalent is the simplest way to keep soldiers happy. Graeber argues that the first person to see a house full of goods simply in terms of its exchange value was most likely a thief, possibly a looter, and that coinage has its origins in rapine and theft. 'Commercial markets originate in theft', ${ }^{18}$ he

\footnotetext{
${ }^{16}$ Simmel, The Philosophy of Money, see p. 427.

17 David Graeber, Debt. The First 5,000 Years (New York: Melville House, 2012 [1 $1^{\text {st }}$ ed. 2011]). See also, e.g. Felix Martin, Money. The Unauthorised Biography (London: Vintage, 2013), a politically conservative work which nevertheless echoes Graeber almost to the word. Martin also stresses the important difference between credit and money. The critique of the theory of barter has a long history; another example can be found in Georges Bataille, The Accursed Share, Volume 1: Consumption, trans. Robert Hurley (New York: Zone, 1991 [1 ${ }^{\text {st }}$ ed. 1949]). Bataille's builds on Marcel Mauss's ideas about potlatch, but goes beyond the mere critique of utilitarianism and into a far more general attack on rank and hierarchy in general, the goals, he argues, of potlatch and its modern variants, not least in the shape of luxury.

${ }^{18}$ Graeber, Debt, 386.
} 
says. Debt, a 'promise corrupted by both math and violence' ${ }^{19}$ can lead to enslavement but also to rebellion. ${ }^{20}$

We must remember therefore that there is nothing natural about money. More to the point, money often exists to hide the origins of the transactions that it facilitates. As Walter Benjamin said: 'Nowhere more naively than in [banknotes] does capitalism display itself in solemn earnest. The innocent cupids frolicking about numbers, the goddesses holding tablets of the law, the stalwart heroes sheathing their swords before monetary units, are a world of their own, ornamenting a façade of hell'. ${ }^{21}$ Money does not emerge independently of the exercise of political power. As the economist Paul Krugman put it, 'money is indeed a kind of theological issue'.22

Argentina is a particularly important case study for theories of money. ${ }^{23}$ The sociologist Geoffrey Ingham, in his volume on money, argues that 'money is not merely socially produced - by mints, central banks, etc. - it is also constituted by the social relation of credit-debit'. ${ }^{24}$ For Ingham, the history of Argentina's politics and economy offers a 'striking illustration of money's "non-neutrality"'. ${ }^{25}$ Ingham argues that the frailty of Argentina's currency - illustrated by the periodic collapses and changes of the national coin - "is the expression of the weakness of its state". ${ }^{26}$ Ingham notes that for much of the

\footnotetext{
${ }^{19}$ Graeber, Debt, 391.

${ }^{20}$ Cuillerai and Kakogianni study this in the context of Greece's position within Europe; see Marie Cuillerai and Maria Kakogianni, 'Bankocracy. Greek Money and the "new idea" of Europe', Radical Philosophy 186 (July-August 2014), 23-28. Using Foucault's history of currencies, they write of 'political money' (24), and its role in the 'monetary repression of states', via a form of 'bankocracy' that works by 'circulating debt to make money solely from money and time' (26). This is close to Streeck's formula, above, with the addition of time and political repression.

${ }^{21}$ Cited in Ericka Beckman, Capital Fictions: The Literature of Latin America's Export Age (Minneapolis: University of Minnesota, 2013), 157.

22 Paul Krugman, 'Beliefs, Facts and Money', International New York Times, July 8 2014, 7.

${ }^{23}$ See e.g. the article by Carlos Aguiar de Medeiros, 'Asset-Stripping the State', New Left Review 55 (Jan/Feb 2009), 109-132, or the volume by Marcelo Bonelli, Un país en deuda. La Argentina y su imposible relación con el FMI (Buenos Aires: Planeta, 2004). David Harvey's The New Imperialism (Oxford: Oxford U. P. 2005) and A Brief History of Neoliberalism (Oxford: Oxford U. P., 2007) both dedicate sections to Argentina's debt.

${ }^{24}$ Geoffrey Ingham, The Nature of Money (Cambridge: Polity, 2004), 198.

${ }^{25}$ Ingham, The Nature of Money, 166.

${ }^{26}$ Ingham, The Nature of Money, 166.
} 
previous century, income tax was paid by only about half of those legally obliged to do so. ${ }^{27}$ In the mid-

1970s the government owed 101 billion pesos to the state social security system; only 48 billion could

be traced, eventually, to the Armed Forces Retirement Fund. ${ }^{28}$ In 2001, the year of Argentina's financial crisis leading to a default on its debt, a sum estimated to be around US\$150 billion had been 'off-shored' by Argentine citizens, a figure roughly equivalent to the national debt. ${ }^{29}$ Ingham concludes that 'the problem of the Argentine economy [reflects] the problem of its feeble monetary system, which, in turn, is a problem of the state'. ${ }^{30}$

Crime and Money

Some of these theoretical considerations are graphically illustrated in the early-twentieth-century fictions of Roberto Arlt. He was writing at a time of rapid social change in Argentina, not least the growth of the middle and working classes and the emergence of new left-wing political parties and organizations, towards the end of the 'liberal period' in Argentina, when parliamentary democracy and universal male suffrage coincided with economic growth and prosperity. ${ }^{31}$ Arlt was a member of the immigrant working classes, an autodidact, and not a natural member of literary circles. ${ }^{32}$

\footnotetext{
27 Ingham, The Nature of Money, 170.

28 Ingham, The Nature of Money, 170.

${ }^{29}$ Ingham, The Nature of Money, 173.

${ }^{30}$ Ingham, The Nature of Money, 173. See also Cara Levey and Daniel Ozarow, 'Argentina: Where Vultures Dare', http://www.aljazeera.com/indepth/opinion/2013/08/201382871453651736.html [last accessed 4 July 2014]) and José Natanson, 'Argentina's Tough Time', Le monde diplomatique (English Edition), July 2015, 5.

${ }^{31}$ The socio-cultural background to Arlt's novels is brilliantly and seminally covered by Beatriz Sarlo in Una modernidad periférica: Buenos Aires 1920 y 1930 (Buenos Aires: Nueva Visión, 1988); see also Tulio Halperín Donghi, Vida y muerte de la República verdadera, 1910-1930 (Buenos Aires: Ariel, 1999).

${ }^{32}$ A writer like Borges could trace his family tree back over several generations, to the very founders of the country; Ricardo Güiraldes, to give another example, was a member of the landed classes; the influential literary magazine Sur was bankrolled by a millionaire heiress, Victoria Ocampo. See John King, Sur: A Study of the Argentine Literary Journal and Its Role in the Development of a Culture, 1931-1970 (Cambridge: Cambridge U. P., 1986). Yet, as Ricardo Piglia has pointed out in a series of televised lectures, 'Borges, por Piglia', available online e.g. at http://www.youtube.com/watch?v=im kMvZQlv8 [last accessed 15 December 2014] in the late 1930s their respective pay slips from journalism jobs show that Arlt was paid almost double what Borges received. Piglia argues, provocatively, that Borges was the poor writer, Arlt the wealthy star.
} 
In his first novel, the semi-autobiographical El juguete rabioso, ${ }^{33}$ money rules the life of the protagonist, Silvio Astier. His family's lack of money prevents him studying, and puts an end to his literary ambitions. His own poverty excludes him from elite circles. This aesthetically appealing world of fine clothes, beautiful women, and conspicuous consumption - is one that stems from inherited wealth. Astier, however, is trapped by the need to make money. While liberal governments in the early twentieth century had presided over economic boom and the growth of the middle classes, in particular through the expansion of the civil service, Astier still forms part of the bulk of new Argentines for whom wealth or success remain only dreams. The routes to progress promised by the system - education, the army, work - are all painfully closed to him.

Arlt was also writing at a time of economic fervent. 1929, the year of his novel Los siete locos, ${ }^{34}$ was the year of the Wall Street Crash. His novels and aguafuertes (contemporary sketches) are full of stories of money won in questionable circumstances, and fortunes lost through bad luck or criminality. Money is a central concern of the majority of his characters, and they show their awareness of living in a society that is obsessed with money. Money-making schemes abound in Arlt's fiction and journalism. Sometimes these are simple. One of the titular 'madmen' in Los siete locos is called 'El buscador de oro'; he is a prospector looking for backers for his gold digging schemes. This is perhaps the oldest moneymaking scheme in the world, and one with obvious resonances in the Americas. Another character, Haffner, known as el rufián melancólico, is a melancholy pimp who tries to combine modern science and the oldest profession, prostitution. He is a former mathematician who applies rational calculation to his brutal treatment of women. As the novel progresses, he is incorporated into the megalomaniacal schemes for world domination of the political agitator and Lenin lookalike, known as the Astrologer.

\footnotetext{
${ }^{33}$ Roberto Arlt, El juguete rabioso (Buenos Aires: Losada, 2003 [1st ed. 1926]).

${ }^{34}$ Roberto Arlt, Los siete locos (Madrid: Cátedra, 1998 [1st ed. 1929]).
} 
Haffner presents his budget for brothels that will fund the revolution. The obsession with making money, the hatred of work, and modern science meet in striking fashion. ${ }^{35}$

The events of the two novels, Los siete locos and Los lanzallamas $(1931),{ }^{36}$ are sparked by a money-crime: Erdosain is a cashier who has embezzled a large sum from his company. No sensible reason is given for his crime. Erdosain, away from his mediocre and poorly rewarded day-job, is also an inventor. His inventions connect modern science and commercial desirability: a copper plated rose, for example. But there is also something rather absurd about them. Copper-plating a rose removes its colour and its smell. In many of the experiments they manage only to burn the rose and ruin the plating fluid. Other inventions and plans are completely ridiculous, such as dyeing and selling pet dogs. But they all rely on science and technology to create something people never realized they wanted and most certainly do not need. Thus Arlt is identifying a feature of early consumerism, in which the middle classes discover a desire for something new but unnecessary, and the inventor or the salesman can make money with it. This is a version of Marx's formula, money-commodity-more money. Erdosain and his colleagues think that invention, and science, is what provides the gap between the initial sum of money and the second larger one. In a sense, Erdosain is trying to make something from nothing, doing so by simultaneously creating and channeling the desire of the consumer. But he fails, very visibly illustrating the importance of unpaid labour in the creation of more money. Perhaps that is why Haffner's plan for scientific prostitution - again, a variant on un(der-)paid work - sounds rather more convincing, if less amusingly picaresque.

The novel opens with a crime, and much of the action and narration consists of plans for more of the same. Murder aside, there are two main felonies in Arlt. ${ }^{37}$ One is that of falsifying or forging

\footnotetext{
${ }^{35}$ On technology in Argentina and Arlt's work in particular see Beatriz Sarlo, La imaginación técnica: sueños modernos de la cultura argentina (Buenos Aires: Nueva Visión, 1992), 229

${ }^{36}$ Roberto Arlt, Los lanzallamas (Buenos Aires: Losada, 2001 [1st ed. 1931]).

${ }^{37}$ On murder in Arlt and elsewhere, see Ludmer, El cuerpo del delito.
} 
money. One tends to think of currency as quite a stable thing. One knows what a banknote is; with advances in printing technology, and with the ever greater percentage of transactions conducted electronically or virtually, printing fake money is not the crime it used to be. But in Arlt's day the possibilities for forgery were far greater. In El juguete rabioso, one of the members of Astier's junior criminal gang is a forger. He has falsified a stamp to win a prize. As with many incidents in Arlt's first novel, this takes a popular childhood activity, collecting stickers, and turns it into a criminal act.

In Los lanzallamas, the protagonist Erdosain meets a pair of forgers. They have a printing press, and he is trying to produce revolutionary propaganda for the quasi-anarchist secret society that he has joined. The forgers print Chilean and Paraguayan money and sell it to foreign forgers in exchange for Argentine notes. The scheme works on the basis that the printing and circulation of forged money is safer if national borders intervene. The scheme operates on a technical basis, namely that someone with a good enough printing press and sufficient skill can make convincing counterfeit money. Indeed in all of Arlt's novels, the suspicion exists that money is not necessarily to be trusted, and that the easiest way to possess lots of it is to make it oneself. Characters want money, by any means. But they also want to be able to make it. Alchemy, forgery, and scientific experiments are all carried out in these novels with a view to creating money out of nothing, or out of dross. This suggests, one might argue, a particular relationship to the state. Money is a promise by a sovereign or a sovereign state to pay. ${ }^{38}$ Money is meant to have an equivalent. For that reason, names for denominations (pound, peso, libra, doblón, etc) are often weights or quantities: that is what, putatively, they were worth in metal. But money is inextricably tied to authority and power. Hence we also talk of crowns, kroner, soles, and so forth. They

\footnotetext{
${ }^{38}$ In this regard, novels of the Mexican revolution make a particularly interesting test case for their depiction of money. See Jose Eduardo González, 'Dinero fingido: Los de abajo y la economía de la revolución', Latin American Literary Review, 35.70 (2007), 57-73.
} 
symbolize the sovereign's credit-worthiness. Institutions like the Bank of England came into being so that the King, or the Crown, could borrow money.

So money in Arlt is related to a half-formed state: strong enough to print money, strong enough to borrow, but not necessarily strong enough to defend the integrity of its currency, and not so well respected that people throughout society do not think that they cannot print their own notes. That, in a sense, is the attempt to turn oneself into a sort of mini-state, or perhaps better, a mini-bank. Argentina has a tradition of collapsing currencies, whereby hyperinflation or devaluation reduce the value of currency (a good way to visualize this is by looking at the cover price of Argentine newspapers or magazines in the mid- to late 1980s). The global financial crisis that was encapsulated by the crash of 1929 was fuelled both by speculation (in particular buying stocks and shares on credit in the hope of further price rises) and by criminal practices by bankers and investors, including forgery. ${ }^{39}$ Inflation and devaluation have been problems for as long as currency has existed (there were credit crunches in ancient Greece, for example, as coins got too watered down with base metal). In Arlt's world, currency, and with it the state, is not especially trustworthy, and everyone seems to know it.

The second major crime that features prominently in Arlt's novels is that of theft. In El juguete, Astier is, among other things, a thief. Erdosain, meanwhile, is an embezzler. Robbers, fraudsters, pickpockets, and housebreakers abound in Arlt's fiction. So he is telling us the story of money from the other side to that of the classic detective. If Holmes, Marple and others are defending a social order in which those without try to steal from those with, often via trickery and/or murder, Arlt is telling the stories of precisely those who are doing the tricking, thieving, and killing. Perhaps what is most striking is that, with the exception of one character in El juguete rabioso, the Engineer Vitri, whom Astier and El

\footnotetext{
${ }^{39}$ Again, such practices have been dealt with in fiction, in Argentina and its neighbours. See Julián Martel's novel La bolsa (Buenos Aires: Estrada, 1946 [1st ed. 1890]), or more recently from Chile, Jorge Edwards' El inútil de la familia (Madrid: Alfaguara, 2004).
} 
Rengo are planning to rob, there are no characters whom one could think of as innocent victims. Even the poor and needy, such as the beggar brothers Espila, turn against each other. ${ }^{40}$

Yet if these are novels about people who need and want money, then characters like Erdosain in Los siete locos have a strange relationship to it. He has enriched himself through theft, but he has nothing to show for it. The money is frittered away:

Entonces gastó el dinero en una forma estúpida, frenética. Compró golosinas que nunca le apetecieron, almorzó cangrejos, sopas de tortuga y fritada de ranas, en restaurantes donde el derecho a sentarse junto a personas bien vestidas es carísimo. (112)

Note the type of things that Erdosain spends his stolen money on: these are the products that are normal for the landed classes and appeal to the rising middle classes: excessive, luxurious food and clothing based on European (particularly French) taste. Erdosain's spending also echoes the potlatch, the ceremonial wastage of some North American indigenous tribes:

Daba abundantes limosnas y solía dejar a los mozos que le servían cuantiosas propinas, todo ello para acabar con los rastros de ese dinero robado. (112)

Some of the money he gives to family friends, to invest in technology for an amateur science lab. Yet he still walks around in battered boots: 'la verdad es que nunca pensé que con plata robada se pudieran comprar esas cosas' (112). This is a key observation: money is fungible and exchangeable. It is not, unlike gift tokens, limited in its potential usage. But Erdosain seems to set up a peculiar divide, a sort of moral hang-up about work and consumption. Stolen money can only be wasted, not spent on anything useful. In part this is because, in his theft, Arlt's character is recreating a feature of consumerism: there are some goods that exist to deal with excess capital. Money needs to circulate, and if it does not, there

\footnotetext{
${ }^{40}$ Óscar Masotta, Sexo y traición en Roberto Arlt (Buenos Aires: Jorge Álvarez, 1965); in this influential study Masotta talks about forms of 'reverse anarchism' in Arlt's fiction.
} 
occurs a crisis of demand. So luxury goods - rich food, fine wines - exist to deal with the potential lack of demand. They are what people spend on when there is too much money; they also reinstate a class divide.

One is thus reminded of a section in Michael Taussig's book The Devil and Commodity Fetishism in South America in which he describes a belief among plantation workers and miners, by which one can sell one's soul to the devil in exchange for quick wealth, but that the money will end up being wasted. ${ }^{41}$ The one who enters into this pact will die an early death. Taussig's reading of this goes against the grain of thinking about so-called primitive belief systems and irrational superstitions. Rather we should read this to see what it says about our own belief system, namely that it shows up a 'superstition' about and within capitalism, namely that capital itself is productive, whereas in fact it is labour that is productive.

Echoing this, the speech that Arlt puts into the mouth of Erdosain reveals another capitalist superstition, namely that money can be good or bad, moral or immoral, and that some ways of gaining money are so immoral that they remove the money from the normal circulation into which one would put it. In part, this is nonsense. Yet money is a social fact. One cannot, unless one is a bank, write oneself a cheque and call it money. One cannot steal money and pretend to have earned it. And this means that the way one earns money has an effect on the way one can spend it. Erdosain steals money above and beyond his usual wage. The social context in which one, through background, upbringing, education and work, earns money and spends it on particular things, is such that money earned outside of that circuit in this case illegally - cannot, for Erdosain, enter into the normal course of life. So money is a form of social brake, a tool of conservatism. Part of Erdosain's conflict with himself is that he has internalized prejudices about who deserves what. When he has extra money, he can only waste it on a parody of the

\footnotetext{
${ }^{41}$ Michael Taussig, The Devil and Commodity Fetishism in South America (Chapel Hill: University of North Carolina, 1980).
} 
excesses of the elite. In doing so, he shows up the hypocrisy of there being any relationship between money and morality. His spending is an attempt to escape that serves only to trap him more securely.

\section{Contemporary Fictions}

As well as promoting the work of Roberto Arlt, not least in the sections on Argentine fiction in the novel Respiración articificial (1981), Ricardo Piglia is perhaps the writer who had done most for the intellectual credentials of the hardboiled or 'negra'. Piglia has enjoyed an almost split career as a writer. Internationally he is famed for difficult, philosophical novels that deal with the history and politics of Argentina, most notably, perhaps, Respiración artificial, an allegorical story about the disappearance of a man during the military dictatorship of the 1970s. His work references Kafka, Joyce, Wittgenstein, and alludes to or mentions the lives of Witold Gombrowicz, Arlt, and others. ${ }^{42}$ He has been, from the 1970 s onwards, one of Argentina's most well-known literary critics. But a key part of his early literary work was dedicated to the translation, publication, and popularization of the 'serie negra', the hardboiled, from the late 1960 s onwards. And his own oeuvre also features two works of crime fiction, Plata quemada (1997) and Blanco nocturno (2010).

Plata quemada is prefaced with a line from Brecht: ‘¿Qué es robar un banco, comparado con fundarlo ${ }^{\prime 43}$ Piglia adopts a particular crime sub-genre, the perpetrator novel, and in this case a further variant, the 'heist'. He tells the story of a town hall payroll robbery, committed by a gang of petty criminals, led by two friends/lovers, known as 'los mellizos', the twins, 'el nene' Bignone and 'el Gaucho rubio' Dorda. Both are hardened criminals, familiar with the insides of prisons and other correctional

\footnotetext{
${ }^{42}$ Piglia, it should be noted, has also written on money in Arlt's writing. See Ricardo Piglia, 'La ficción del dinero,' Hispamérica 3.7 (1974), 25-28.

${ }^{43}$ Ricardo Piglia, Plata quemada (Buenos Aires: Anagrama, 2000 [1st ed. 1997]), 9.
} 
establishments. But they are also carrying out what amounts to an inside job: corrupt employees, local politicians, and unionists, all stand to gain from their crimes.

A strong journalistic element features in the novel. Piglia based it, loosely in parts, on a true-life robbery and shoot-out that occurred in Buenos Aires and Montevideo in 1965. He carried out his own investigative research, although unlike Rodolfo Walsh and his pioneering 'true crime', Operación massacre, ${ }^{44}$ took rather more liberties with the description of characters, events, and chronologies. His prose style is sensationalist, showing greater care for directness and emotion than for subtlety and precision. Piglia thus uses elements of the hardboiled to describe a real-life tale. The novel includes copious amounts of violence, sex, and gratuitous acts. He writes passages full of contemporary details and physical description. There is a notable tendency towards over-adjectivization, describing characters - particularly their appearance and personality - with a wealth of detail, in a fashion that is perhaps far from sophisticated. The writing is full is of profanity and street slang. Like Operación masacre, the novel is compelling and effective, indeed a page-turner. Thus he follows his own character, Emilio Renzi's suggestion about Roberto Arlt, contra Borges, in Respiración artificial that one can be a great writer precisely because one writes badly. But it is also a composite style: descriptions are often relayed as told by a witness, or as written by a journalist, or even as described by Emilio Renzi, the investigator and focaliser of the novel (and former pseudonym of Piglia himself).

The novel is perhaps most memorable for one set piece, involving the titular protagonist, money. Knowing that they are surrounded, and realizing that all their erstwhile allies and friends have deserted or betrayed them, the robbers decide to destroy the fruit of their efforts: in defiance, provocation, and - for the watching public - final proof of their pure evil, they set fire to the money and

${ }^{44}$ Rodolfo Walsh, Operación Masacre (Buenos Aires: 451 Editores, 2008 [1st ed. 1957]). 
fly the flaming bank notes, like 'mariposas de luz', ${ }^{45}$ out of the window of their hideout down onto the crowds below. This is a perverse reworking of the munificence of the king or millionaire, throwing money - gold coins or bank notes - down to the faithful below, or of the potlatch mentioned above. ${ }^{46}$ The twins throw, or float, burnt money, and with this gratuitous gesture, this quasi-ceremonial destruction, turn themselves into pariahs.

Up until this point, there has been a sort of macabre fascination among the general public with regard to the crimes of the gang, as well as a certain grudging admiration for the ill-gotten gains of these latter-day bandits. ${ }^{47}$ But by burning the money they put themselves beyond the understanding of the public. This is a crime for crime's sake, with no material gain available. As the narrator says,

Si la plata es lo único que justificaba las muertes [...] y ahora la queman, quiere decir que no tienen moral [...] Indignados, los ciudadanos que observaban la escena daban gritos de horror $y$ de odio. (172)

One TV journalist goes as far as to say that 'Quemar dinero inocente es un acto de canibalismo' (173).

What Piglia is trying to explore is the extent to which this crime and the ensuing madness (and it is worth mentioning that several of the robbers do appear to have suffered significant psychological damage in the years before the main action of the novel) reveal a society that fetishizes money as an object. To burn money is inhuman, it is to destroy life; it is, as the onlooker observes, a form of 'cannibalism'. Although that is exaggerated, it points to a fact: that the observers in the novel see money

\footnotetext{
${ }^{45}$ Piglia, Plata quemada, 171

${ }^{46}$ This has been reworked in film, as in Tim Burton's first Batman movie (1989), in which under the guise of handing out free money, the Joker gases the crowds. The pioneering work on potlatch is Marcel Mauss, The Gift. The Form and Reason for Exchange in Archaic Societies, trans. W.D. Halls (London: Routledge, 2002 [1 $1^{\text {st }}$ ed. 1925]), an attack on utilitarian theories of exchange that sought to identify in potlatch a complex system of honour and rank, not based on need or accumulation, nor explicable at an individual level. Instead, the potlatch of North American indigenous peoples, and similar practices found in Polynesia, could be described as 'total services of an agonistic type', in which 'rivalry and hostility' played an important role (8). In the gift, therefore, 'obligation and liberty intermingle' (83).

${ }^{47} \mathrm{I}$ use the term in the sense explored by Eric Hobsbawm in Bandits (London: Abacus, 2001 [ $1^{\text {st }}$ ed. 1969]).
} 
as having a life of its own, and indeed as having something akin (or even superior) to human life. Money is not just a tool for universal exchange (as Simmel might put it in The Theory of Money). Yet Piglia's readers have followed closely the lives of the gang, and seen them in contrast to a police force, and indeed a wider society, that is at best self-serving and at worst utterly corrupt. Thus it is hard not to see a certain maniacal grandeur in their gesture, and some dignity in their last stand, holding out until the bitter end against the massed ranks of the cops. The thieves become scapegoats, sacrificed for inequalities and injustices in society that certainly are not their fault. They come to embody Brecht's words: they are criminals, but there are far worse criminals, and the latter never have to suffer for their crimes as these men do. They are, furthermore, criminals who reveal a deeper criminality at the heart of society.

Ernesto Mallo, in his 2006 novel about crimes during the dictatorship of the 1970s, La aguja en el pajar, has two of his characters discuss a large sum of money they have found. ${ }^{48}$ Eva, a militant on the run from the military, has found a stack of used notes in a brothel. She shows it to Lascano, the only good cop in town. ${ }^{49}$ Lascano insists that they hand it in. To whom, she asks. To the law, he replies. But it is ours, she argues, drawing Lascano's attention to the words on the note: pay the bearer. It belongs to the person who holds it. Eva thus takes money at face value, re-signifying its fiction by reading it literally. In the next book in the series, Delincuente argentino, two characters discuss money stolen in a bank raid. ${ }^{50}$ Lascano, the cop, has cornered the robber, Miranda, who offers him a deal: a cut of the cash in exchange for freedom. Lascano refuses. He has been promised a pay-off from the bank as a reward. But what is the difference between two sources of money, asks Miranda, who is offering more. Lascano

\footnotetext{
${ }^{48}$ Ernesto Mallo, La aguja en el pajar (Buenos Aires: Planeta, 2006).

${ }^{49}$ In an interview with the BBC Radio 4 series Foreign Bodies (broadcast 9 Jul 2013 13:45), Mallo argued that despite the widely held belief that the Argentine police force was entirely corrupt, and especially so under the dictatorship, it was statistically impossible for there not to be one good cop. See http://www.bbc.co.uk/programmes/b036k8vg [last accessed 2 July 2014].

${ }^{50}$ Ernesto Mallo, Delincuente argentino (Buenos Aires: Planeta, 2007).
} 
responds that the difference between money from a bank-robber and money from a banker (even a corrupt one) is whether someone comes after him or not. Miranda insists that there is no difference: cash, for him, means freedom, the freedom to spend and the freedom to decide. But gifts, Lascano insists, come with obligations: the only freedom on offer is Miranda's own. ${ }^{51}$ In a novel set in the mid1980s in Argentina, though, Lascano comes to discover that the bank-robber is more trustworthy than the bank - a latter day Bertolt Brecht, one might say. What is more, Mallo is illustrating the 'nonneutrality' of money, in Ingham's terms, and with it the need for a repressive apparatus (of state, or of private companies operating with the compliance of or simply power over the state) to enforce the relationship between debtors and creditors.

In Carlos Gamerro's diptych of novels about the armed struggle of the 1970s and its legacy in the 1990s, La aventura de los bustos de Eva and Un yuppie en la columna del Che Guevara he creates a series of memorable sequences dealing with money. ${ }^{52}$ The novels tell of a corporate executive, Marroné, who as part of a Machiavellian plot by a megalomaniacal businessman finds himself infiltrating an armed left-wing guerrilla group. One of them has kidnapped the owner of the company Marroné works for, and among their conditions for release is the demand that a bust of Eva Perón be placed in every one of the company's premises. Marroné, as head of purchasing, is tasked with sourcing these busts, a job that takes him on a bizarre tour of Buenos Aires and clandestine political militancy. La aventura ends with Marroné failing in his mission, and seeing his boss, the kidnappers, and two million dollars go up in smoke. All that remains of Tamerlán, or so it seems, is a pile of burnt flesh, and the one, intact finger that his kidnappers sent as proof of life.

\footnotetext{
51 In a sense, Lascano is echoing Mauss's and Bataille's work on potlatch, mentioned above.

${ }^{52}$ Carlos Gamerro, La aventura de los bustos de Eva (Buenos Aires: Norma, 2004); Un yuppie en la columna del Che Guevara (Buenos Aires: Edhasa, 2011). Gamerro has written both a version of the detective novel, El secreto y las voces (Buenos Aires: Norma, 2002) and an essay on crime fiction in an Argentine context, 'Para una reformulación del género policial argentino' (in 'El nacimiento de la literatura Argentina' y otros ensayos (Buenos Aires: Norma, 2006).
} 
The novel thus focuses on a tactic of armed leftist groups, the extortive kidnap. Throughout the 1970s, such groups sequestered businessmen, diplomats, and political figures. In some cases, they did this for money, and several multi-million-dollar ransoms were paid for the return of business leaders. Political concessions, or the liberating of comrades, were also granted. In some cases, individuals were targeted for revolutionary justice, as it was called; General Aramburu, one of the leaders of the coup against Perón, and likely to have been involved in the disappearance of Evita Perón's corpse, was kidnapped and killed by Montoneros in the early 70 s.

There were incidences of Stockholm syndrome, too. Jorge and Juan Born, directors of one of Argentina's largest industrial companies, were kidnapped by Montoneros. After their release - the company paid a ransom of $\$ 60$ million - Juan Born went on to befriend one of his kidnappers, Rodolfo Galimberti, and the latter became an advisor on security matters to Juan Born's companies. For some commentators, this demonstrates a plot between the military, the political establishment, and left wing groups, to create the conditions for a civil-military crackdown. ${ }^{53}$ In Gamerro's reading, instead, he sees the ease with which the disorganized and defensive left is infiltrated and defeated by the militarycorporate nexus. Furthermore, in the shape of the repentant guerrillero, Marroné, a man who has gone from yuppie to resistance fighter and back again, we see the ease with which the corporate machine can swallow up oppositional discourses. He successfully passes as a member of the guerrilla. His self-help books and management thinking allow him to morph effortlessly into a member of the resistance. But later he repents, betrays his comrades and his one true love, the guerrillera known as Comrade Eva, and

\footnotetext{
${ }^{53}$ For discussion of this see the works by Pilar Calveiro, Poder y desaparición: los campos de concentración en Argentina (Buenos Aires: Colihue, 1998) and Política y/o violencia. Una aproximación a la guerrilla de los años 70 (Buenos Aires: Norma, 2006); Jose Amorín, Montoneros: La buena historia (Buenos Aires: Catálogos, 2006); Roberto Mero, Conversaciones con Juan Gelman; contraderrota. Montoneros y la revolución perdida (Buenos Aires: Contrapunto, 1987); and Richard Gillespie, Soldiers of Perón. Argentina's Montoneros (Oxford: Clarendon, 1982). In fiction, see Horacio Vázquez-Rial's novel Historia del triste (Historia del Triste. Barcelona: Destino, 1987), which presents a striking, albeit highly dubious, vision of the far-right-Montoneros nexus.
} 
returns to this former, bourgeois life. Meanwhile, the genius of the business mogul Tamerlán is that he can survive his time in captivity, learn from it, and manipulate it to his advantage.

Money in these two novels appears as an object, in particular in the form of notes, suitcases full of them, dollars by preference. The importance of dollars is the flipside to the instability of Argentine currency as sketched by Ingham, above. The mid 1970s were characterized by massive inflation and currency devaluation. In the 1980s, Argentina experimented with a variety of currencies, including from 1985 the austral, only then to return to the peso after that one collapsed. Dollars are seen as at once reliable and stable. In the novels they travel in large suitcases, generally as part of a ransom. As a foreign currency, they give the impression of un-traceability. They are also easily smuggled out of the countryas was the case with much of the money collected in ransoms. That multinational companies possess, in Gamerro's novels, such large sums in foreign capital is revealing of businesses' simultaneous lack of trust in local currency and ability to move capital beyond national borders. ${ }^{54}$ This is a long-standing problem in Argentina, as profits made nationally then leave the country by one means or another. Property purchases, to this day, are routinely carried out in dollars (in cash). ${ }^{55}$ So cash is a mark of local instability, international imbalances, and the close ties between business and criminality (indeed Tamerlán's business empire is perhaps the biggest criminal in the two novels).

A suitcase full of money is one of the main characters in Alan Pauls' novel, Historia de dinero. ${ }^{56}$ The novel forms part of a trilogy, each one the '(hi)story' of something. Historia del llanto (2007) is a

\footnotetext{
${ }^{54}$ David Harvey, in A Brief History of Neoliberalism (Oxford: Oxford U. P., 2007) and The New Imperialism (Oxford, 2005), makes important observations about the role of petrodollars (the product of pricing oil in dollars) and their role from the 1970 s onwards in the spread of US political and military hegemony.

${ }^{55}$ A number of recent policies have been introduced to encourage the 'onshoring' of capital, or at least the legitimate exchange of currency, rather than the use of black-market dollars to take money out of national circulation. This has included a government-backed certificate, the CEDIN, accompanied by a tax amnesty. See Buenos Aires Herald, 'Tax amnesty extension made official by gov't', 1 April 2014 http://www.buenosairesherald.com/article/155961/tax-amnesty-extension-made-official-by-govt [last accessed 4 July 2014].)

${ }^{56}$ Alan Pauls, Historia del dinero (Buenos Aires: Anagrama, 2013).
} 
novel, ostensibly, about a boy who cannot cry. Historia del pelo (2010) tells of a very hairy man, and his obsession with hair. But despite these seemingly banal topics, the novels approach from their strange angles decisive moments in the recent history of Argentina. Pauls is a digressive novelist; his critically acclaimed El pasado (2003) consisted in large part of the most bizarre detours from anything like a plot, including the life-story of an experimental artist, Riltse, who uses his body parts and fluids to create works of what he calls 'sick art'; the tale of the Argentine adman who brings one of these works, Bogus Hole, back from Europe; and how the protagonist comes to steal the painting from the house of his lover and tennis partner. In Llanto and Pelo, this digressiveness is manifest in his prose style: lengthy, almost paragraph long sentences, full of asides and sub-clauses, so that one has to read slowly, constantly referring back, in order to unpick the sense of the construction.

Historia del dinero takes a similar approach, but with an almost pornographic treatment of money. The novel tells the story of the protagonist's relationship to money, and in particular its central role in his family life. Aged fifteen he sees his first corpse, a friend of the family who has died in a helicopter accident. His family is close to the local haute bourgeoisie, a semi-criminal collection of businessmen and their families with shady links both to corrupt unions and the repressive apparatus of state. The friend of the family has been travelling by helicopter with a suitcase full of money, heading for a factory where industrial action is taking place. The reasons for the flight remain unclear - the money may be to pay off the workers, or to bribe union officials, or to finance police repression to break the strike. However, on the way, the helicopter crashes. The money disappears - the only thing that does in the accident. This, one would think, is the classic start of the hardboiled crime thriller (a detective would investigate the disappearance). But it is not, as Pauls toys with the genre.

The novel never properly explains the opening incident. Its structure is again highly digressive, following money-making schemes and financial ups and downs, and often seeing segments trail off or 
come to a dead end, like the story of the helicopter crash. The protagonist grows up surrounded by money-obsessives. His father is a wheeler-dealer, involved in tourism, frequenting casinos and gambling clubs, constantly in contact with money: currency deals, buying and selling, counting, handling, and moving notes. He is skilled at dealing with money, but cash leaves no mark on him: it never stains his fingers. His mother, meanwhile, spends the fortune she inherits and the money from her second marriage on the trappings of wealth and success - clothes, food, travel, and properties, including a failed investment in an ever more dilapidated holiday complex.

There is in the central character's youth something magical about money, the narrator tells us: it is a small, portable item that, like a magic wand, is capable of 'eating' other things (31). The novel marvels at insurance policies, in which the value even of a life can be measured (78-79). The protagonist's relationship to money is highly emotional: during his divorce, it is the closure of the couple's joint bank account that most hurts him (127). For his mother, money is constantly divorced from work; for her the perfect money is 'la plata de los muertos', 'la plata que cae', the money that falls or rains down, money that simply appears without one having to lift a finger (143, italics in original).

The idea of money that 'rains down' is shown in Carnivalesque fashion in the funniest moment in the book. The protagonist gets a small job running a film club for a friend of the family who owns a video outlet. His job is to introduce and then comment on movies for an audience of senior citizens. In the final week the film is Sergei Eisensteins' epic Ivan the Terrible (1944/1958). The film reaches the scene in which the Tsar is crowned, and gold coins are poured over his head to show his wealth. ${ }^{57}$ But unbeknown to the protagonist, behind him on the screen, the image has changed. He carries on explaining the sequence, only to realise that no one is listening. He turns around and sees, instead of

\footnotetext{
${ }^{57}$ This sequence is also analysed by Slavoj Žižek in his work on Gilles Deleuze, Organs without Bodies: Deleuze and Consequences (New York: Routledge, 2003).
} 
Eisenstein's 'money shot', as it were, a sequence from a Brazilian pornographic film, in which two men and a woman are having energetic three-way sex. It becomes immediately clear both why his audience is stunned and silent, and what his friend's real business is (importing pornography). Then, just like that, the film cuts back to Eisenstein. Pauls is playing on that earlier phrase - 'la plata que cae' - money that rains down, like what one imagines will soon 'rain down' in the smut film. ${ }^{58}$ Pornography is a lucrative business, one of the ways in which money 'just fell' into Argentina in the 1970s and again in the 1990s the so-called 'plata dulce' of cheap foreign loans and easy consumer credit. If, as the emperor Vespasian once said, pecunia non olet - money doesn't smell (he was proposing a plan to tax urine) - then what makes it may well stink. So money is a way of cleaning up dirty business, and characters in Pauls' novel are constantly using money to make themselves, hypocritically, whiter than white.

Yet money is always a problem in the novel. For the protagonist's mother, money is by definition never enough (176). For his father, it is an obsession, almost a sign of his manhood. He finds in his father's house seven notebooks which cover his financial history - what the novel calls his father's 'autobiografía contable' (183). The protagonist reflects on the possibly utopian function of money, for example to invest in a factory to change its organization and purpose, as a substitute for revolution (206). But the plan never comes to fruition.

The denouement of the novel is a stunning image of money's function. His mother has abandoned her flat and gone to live with friends, leaving almost everything. It falls to the protagonist to clear out her former home. There he makes a discovery: the flat is full of money. Not large sums, but small and smallish sums, rolled up, tucked away, or hidden. His mother has been collecting money (207-

\footnotetext{
${ }^{58}$ The OED online defines the 'money shot' thus: 'n. U.S. colloq. (a) Sport a shot on which the outcome of a match, etc., depends; a very important shot; [...] (b) a provocative, sensational, or memorable sequence in a film, on which the film's commercial performance is perceived to depend; spec. (in a pornographic film) one showing ejaculation (= come shot [...]); (also in extended use) a crucial or pivotal moment, event, or factor, esp. in another art form, as a novel' http://www.oed.com/view/Entry/121171?redirectedFrom=money+shot\#eid36245295 [last accessed 3 October 2014].
} 
208). All the sums of money that he has given her over many years, and perhaps other amounts from other sources, have been squirreled away in the flat. The implication seems to be that she never needed the money that she constantly demanded of her son. Is this because the missing money from the helicopter crash ended up in her possession? Much of the money is not even legal tender anymore. So this is money that has no value, but tells a story - yet it does so in 'una lengua muerta' (208), a dead language or, perhaps one might hazard, something approaching a "private language" in the term analysed and criticized by Ludwig Wittgenstein. ${ }^{59}$ The only two people who speak this language are the protagonist and his mother. If, for Ingham, money was a socially constituted relationship, this money is that relationship reduced to the very barest essentials: the relationship between mother and son. The latter is not a relationship that one usually thinks of in terms of money. Money is stripped of its value and its power in circulation. Money, then, has been translated. Out of circulation, it ceases to be a universal equivalent, it ceases to have social meaning, and instead becomes the weak, even insalubrious link between a mother and her son. The emotional investment in now worthless tokens is a form of excess, a plus to its ability to represent exchange value. This is a graphic illustration of money's fragility in Argentina.

\section{Conclusion}

One may argue, in conclusion, that these novels all relate in different ways to theories of money, and offer instances of how money is read at different moments in Argentina's history. Through a broad understanding of the crime genre, one can identify points of contact between novels distant in time and technique. Against the general background of the theory of money as a socially constituted relation, one that relies on a state or a sovereign or the equivalent's power, while insisting on money's non-neutrality

\footnotetext{
${ }^{59}$ Ludwig Wittgenstein, Philosophical Investigations (Oxford: Basil Blackwell, 1967 [1 ${ }^{\text {st }}$ ed. 1958]).
} 
and political function, one might identify four specific sub-theories of money in Argentine crime novels: Roberto Arlt sees money as a form of falsification and alchemy at a time of the liberal state's weakness and collapse. Through his interest in anarchism, political plots, and individual rebellion, Arlt uses money as a lens through which to examine contradictions of the contemporary Argentine bourgeoisie, desperate to escape from the control of money yet still trapped by the morality and social control that it imposes. Piglia's Plata quemada portrays money as a fetish, a bourgeois obsession, and a mask for greater crimes. Money is a tool used to cover up criminality, conferred with a strangely moral or even sacred quality by River Plate society in the 1960s. It is this façade the robbers so savagely shatter with their robbery and final potlatch. For Gamerro, physical money works as a sign of international capital's power over the nation state. The dollar is an all-powerful tool of financial and political control. His armed rebels of the 1970s are viewed through the prism of dollar-peso parity and convertibility and the flow of easy money that so marked the 1990s in Argentina. The yuppie owes his peace and prosperity to violent repression and its hypocritical disavowal. Finally, for Pauls, money is intrinsically linked to crime, and psychologically is manifested in a type of almost meaningless hoarding. All money is dirty, and only the most skilled - like the protagonist's father - can keep their hands clean. When family relationships break down, money remains as a near-private reminder of the ties that have been broken.

Money, then, is a key theme and actor in crime novels in Argentina, and these provide graphic and compelling illustrations of the intractable relationship between money and politics. ${ }^{60}$ If as Ingham noted, and as was quoted above, 'the problem of the Argentine economy [reflects] the problem of its feeble monetary system, which, in turn, is a problem of the state', ${ }^{61}$ these novels carry out a striking

\footnotetext{
${ }^{60}$ This nexus extends beyond Argentina. Many recent so-called 'narconovelas' from northern Mexico also discuss money at length; Contrabando, the posthumous novel by Víctor Hugo Rascón Banda, includes a section on investment strategy for those involved in the drug trade (Mexico City: Planeta, 2008, 121-2). One is reminded of the sequence in the television series The Wire in which an aspiring drug lord reads Adam Smith for advice on questions of supply and demand.

${ }^{61}$ Geoffrey Ingham, The Nature of Money, 173.
} 
investigation of how that problem has developed over the century, from the collapse of the liberal order in the 1930s, through fragile and often hypocritical democracies of the 1960s, via the implosion of Peronism into military violence and failed armed insurgency in the 1970s, to the corruption and graft of IMF-compliant Argentina in the 1990s. All the novels acknowledge the international context in which this takes place. Crime is society in miniature. 